\section{ARCHAEOLOGICAL FEATURES}

The excavation identified both settlement and funerary activity across Areas A and B from the Bronze Age and Iron Age (Illus 3 and 4). Bronze Age activity included four urned cremations, a possible tree root hollow with the cremated remains of two individuals within it and a pit group with a ceramic vessel and a grinder. The Iron Age activity comprised a large roundhouse and a souterrain. A feature group in Area B comprised of a curvilinear ditch and several pits could not be accurately dated, but is probably contemporary with other features on the site, based on associated fragments of pottery.

\subsection{Structure 1}

Structure 1 was located on a very slight slope in the north-west corner of Area A and comprised two curvilinear ring ditches and two post holes (Illus 3 and 5). The ring ditches appeared to have been formed from erosion rather than as cut features. The topography of the area sloped gently from west to east and the incline required the structure to be partially dug into the slight slope. The remains of Ring Ditch 187 were more extensive than the opposing ditch to the north (Ring Ditch 189) and included poorly sorted large stones within the homogeneous fills (Illus 6). Together, the two ring ditches in plan had an external diameter of $9.3 \mathrm{~m}$. The only internal feature was a linear gully (Ditch 195), which had an uneven base with two depressions that may have been the remnants of post-pads to support internal fittings. Two post holes were located to the south side of the structure and may have been potential structural features such as roof and wall supports. No ring groove with stakeholes was present on the perimeter of the structure, therefore it is likely that the outer wall was formed of turf and had an opening to the east in line with the axis of the ring ditches.

A sample of alder charcoal from the upper fill of Ring Ditch 187 was radiocarbon-dated to 1415-1260 cal BC (SUERC-93919; Table 1). The sample was recovered from the natural, upper fill of the ditch, after it had been abandoned and silted up, but could potentially be associated with the occupation of the structure, as it was relatively isolated from other features and further upslope. With no other hard dating evidence for Structure 1, it is possible that it is contemporary with Iron Age Structure 2 (see 3.4). However, the nature of the construction of Structure 1 , cut as it is into the slope, is more characteristic of Bronze Age than Iron Age building and thus the radiocarbon date from Structure 1 has been used, with caution, to date the occupation of the structure.

\subsection{Urned cremation burials 094, 097, 126 and 129}

Four urned cremation burials were located in the centre of Area A with Pits 097, 126 and 129 in a cluster and Pit 094 approximately $6 \mathrm{~m}$ to the southeast. In general, the pits were shallow, steeply sided and had flat bases, with each containing an inverted bucket urn. All four urns, and possibly also the pits, had been truncated to differing degrees, with Vessel 5 in Pit 129 being the worst preserved (Illus 7). The truncation is also likely to have resulted in the loss of some of the cremated bone. It is unknown when this truncation occurred, but it is assumed that the agricultural practices of the post-medieval period would have had a significant impact on the survivability of the archaeology. As the pits survived to a depth of $0.1 \mathrm{~m}$, and assuming the present ground level is similar to that in the Bronze Age, it is assumed that the bases of the urns were above ground level and therefore potentially covered with a mound of earth. A summary of the urned cremation burials is presented in Table 2. Further details, discussion and illustration of the pottery is presented further in the text (4.1; Illus 18) and a discussion of the associated charcoal is presented in 4.7.

The cremated bone was subjected to osteological analysis. The minimum number of individuals was determined by the absence of repeated skeletal elements and age-related changes to the bone. Each vessel appeared to contain a single individual, mainly represented by skull vertebrae, rib and long bone fragments. Pits 097 and 129 contained probable adults, based on the size and robusticity of rib fragments. Pit 094 contained bones from a child aged between one and six years at the time of death. A fragment of the child's femur was radiocarbondated to 1385-1260 cal вс (SUERC-93920; Table 1), placing it in the Middle Bronze Age. The bone fragments from Pit 126 could not be used to determine the age of the individual. 


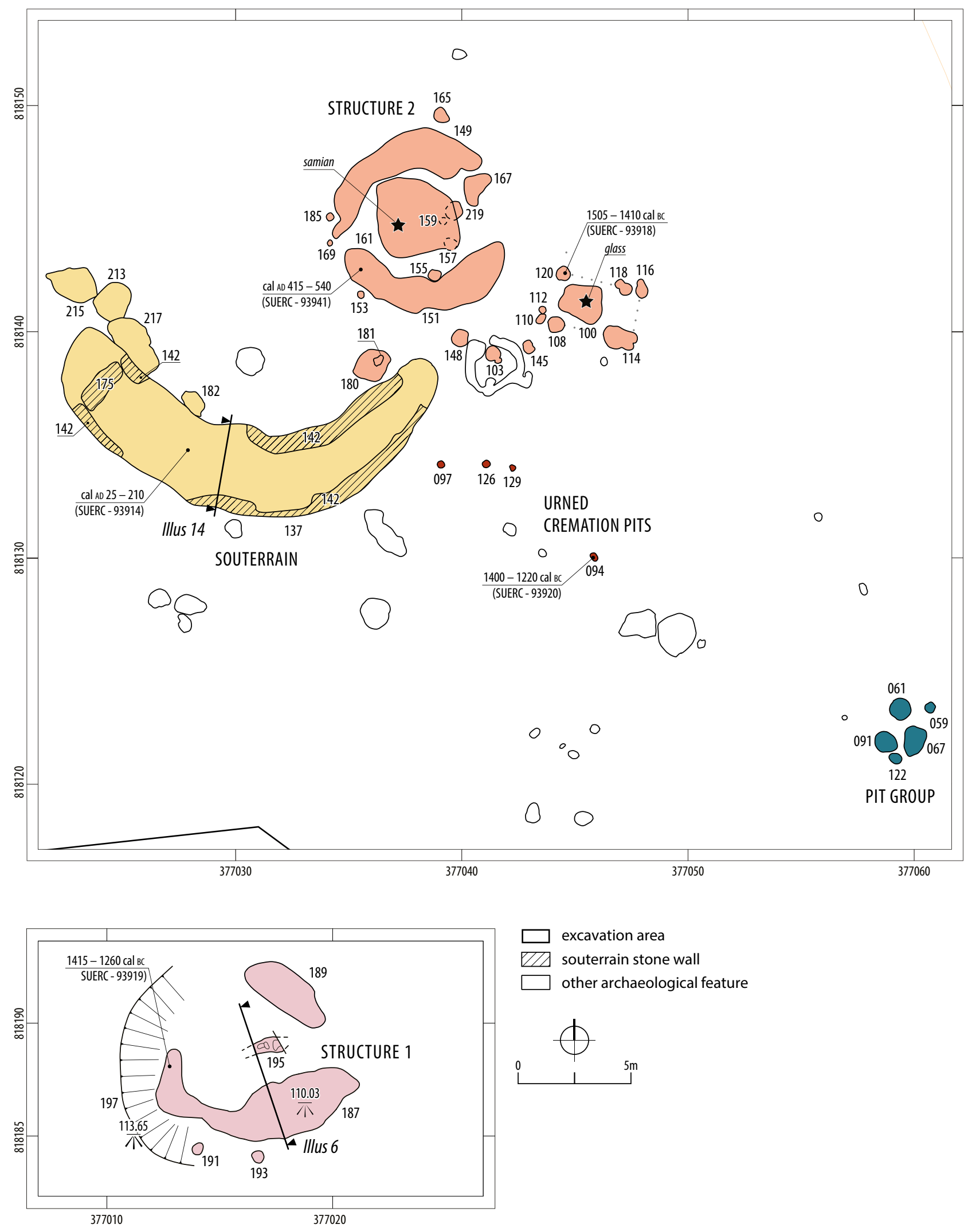

Illus 3 Archaeological features in Area A 


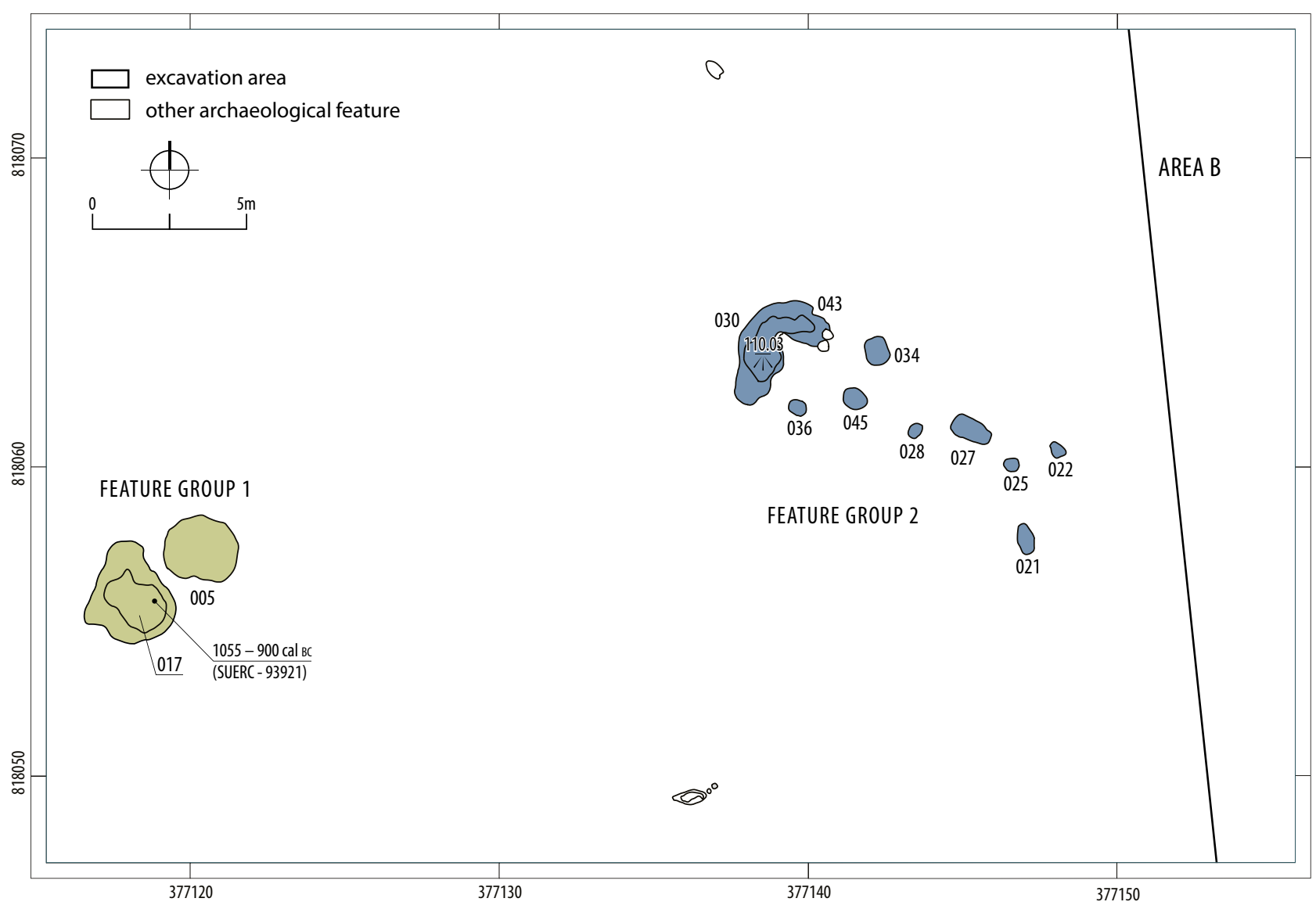

Illus 4 Archaeological features in Area B

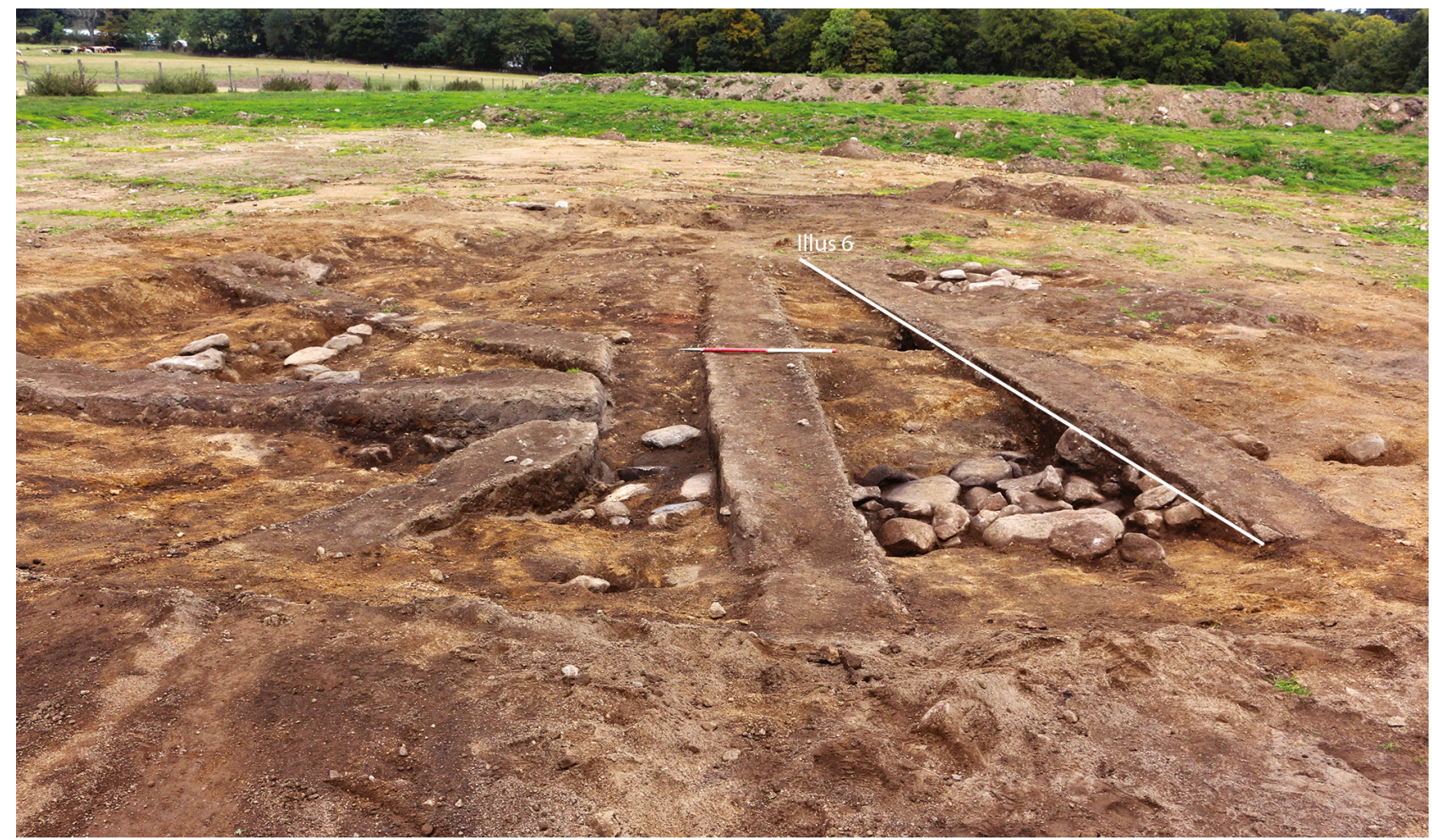

Illus 5 Structure 1, facing north 


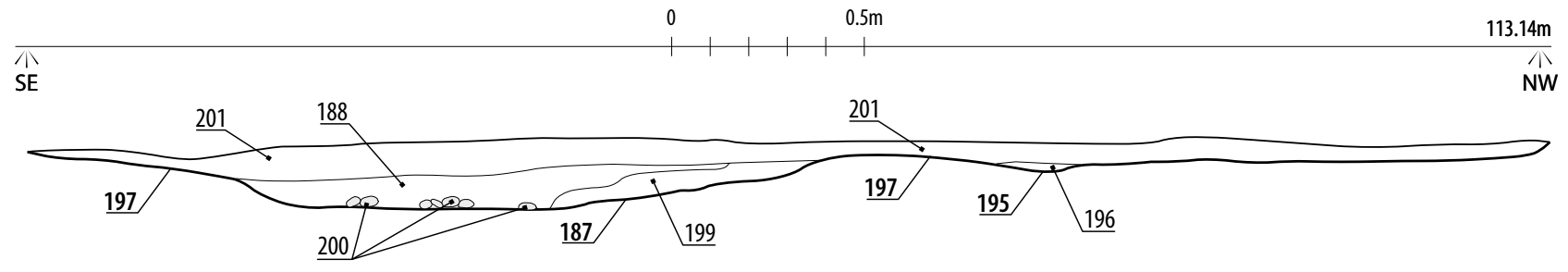

Illus 6 East-facing section through Structure 1

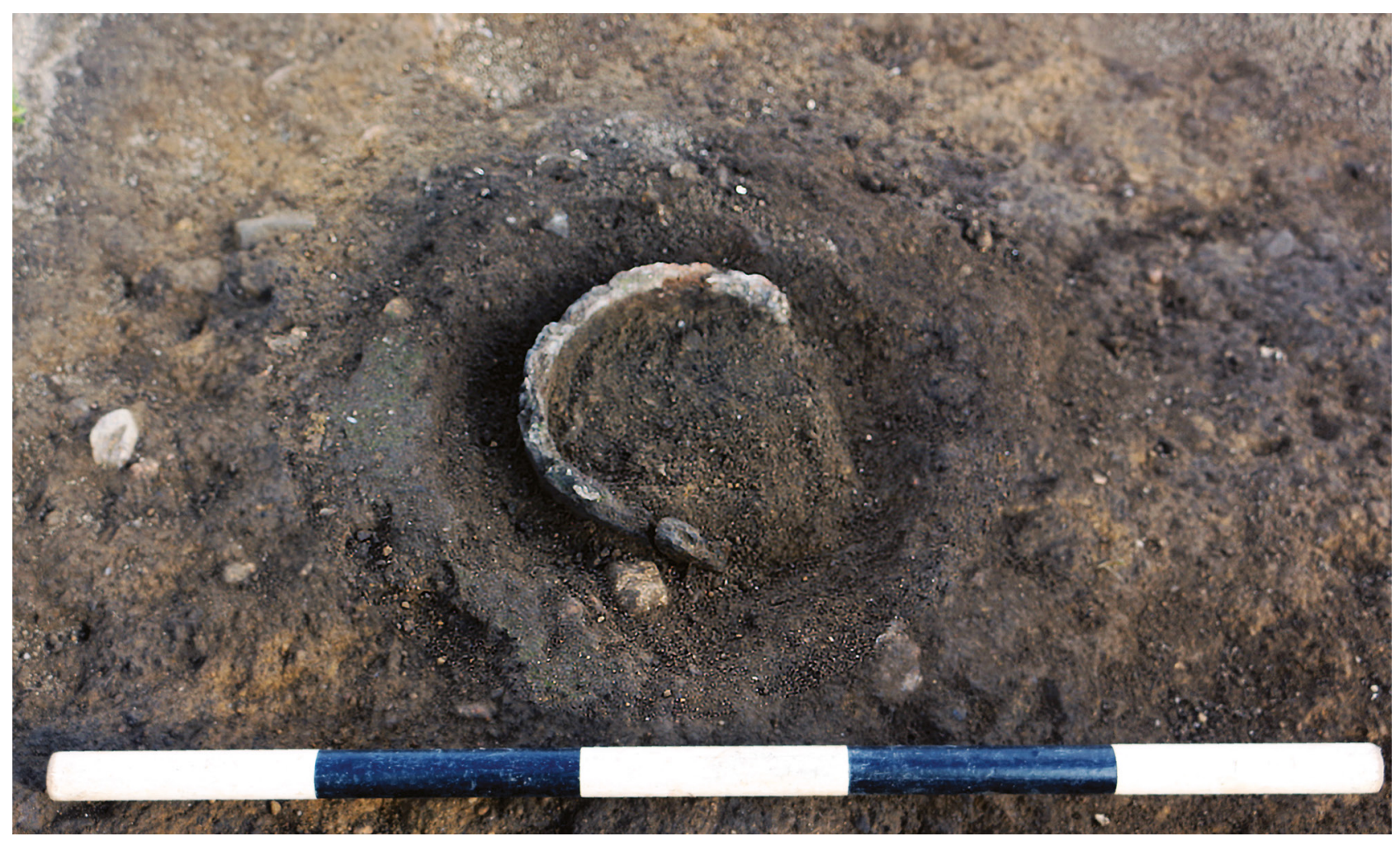

\section{Illus 7 Vessel 5 within Cremation Pit 129}

All bone was a uniform white colour, indicating that it was fully oxidised and cremated at temperatures over $600^{\circ} \mathrm{C}$ (McKinley \& Bond 2001; McKinley 2004; Mays 2010). Cracking and U-shaped fissures were present on the outer bone surface of many fragments, which indicated dehydration of organic material. This also suggested that soft tissue was present at the time of burning (McKinley \& Bond 2001).

\subsection{Pit group (Pits 059, 061, 067, 091 and 122)}

A cluster of five pits was located in the south-east of Area A. Prior to excavation, these were assumed to be associated with funerary activity based on the presence of an urn in Pit 091 (Vessel 1, Illus 8). The infill of the pit was comprised of silty and clayey sand with inclusions of burnt bone and charcoal. The vessel was similar to those found in the urned cremation pits to the north-east, but it did not contain cremated human bone, was upright instead of inverted and had a stone lid (see 4.1 and 4.8 below for further discussion of this vessel and associated material).

Pit 067, to the east of Pit 091, also contained fragments of pottery (Vessel 6), which was similar to those present in the urned cremations. Residue was present on the interior surface, indicating domestic use of the vessel (see 4.1). 


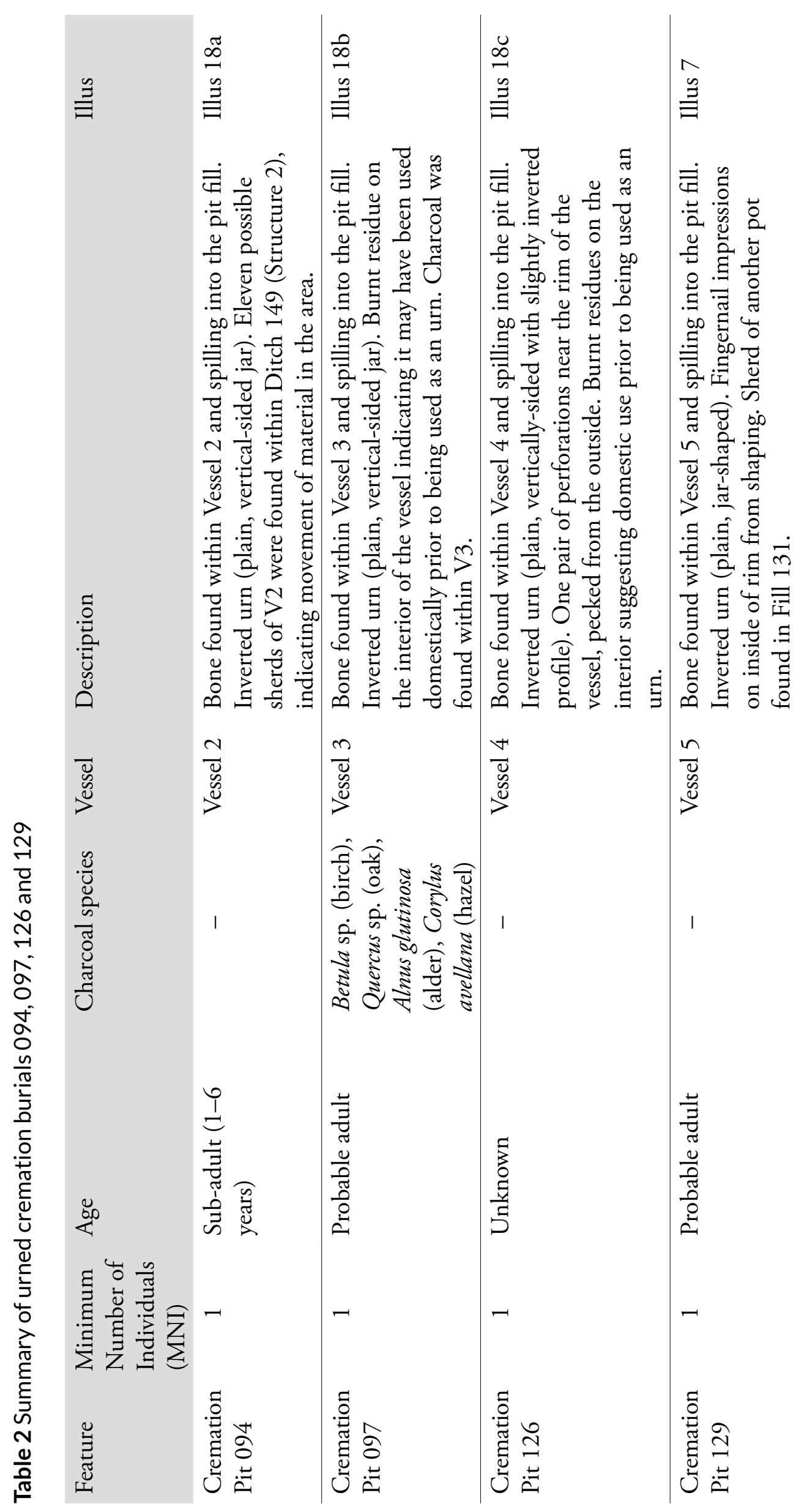




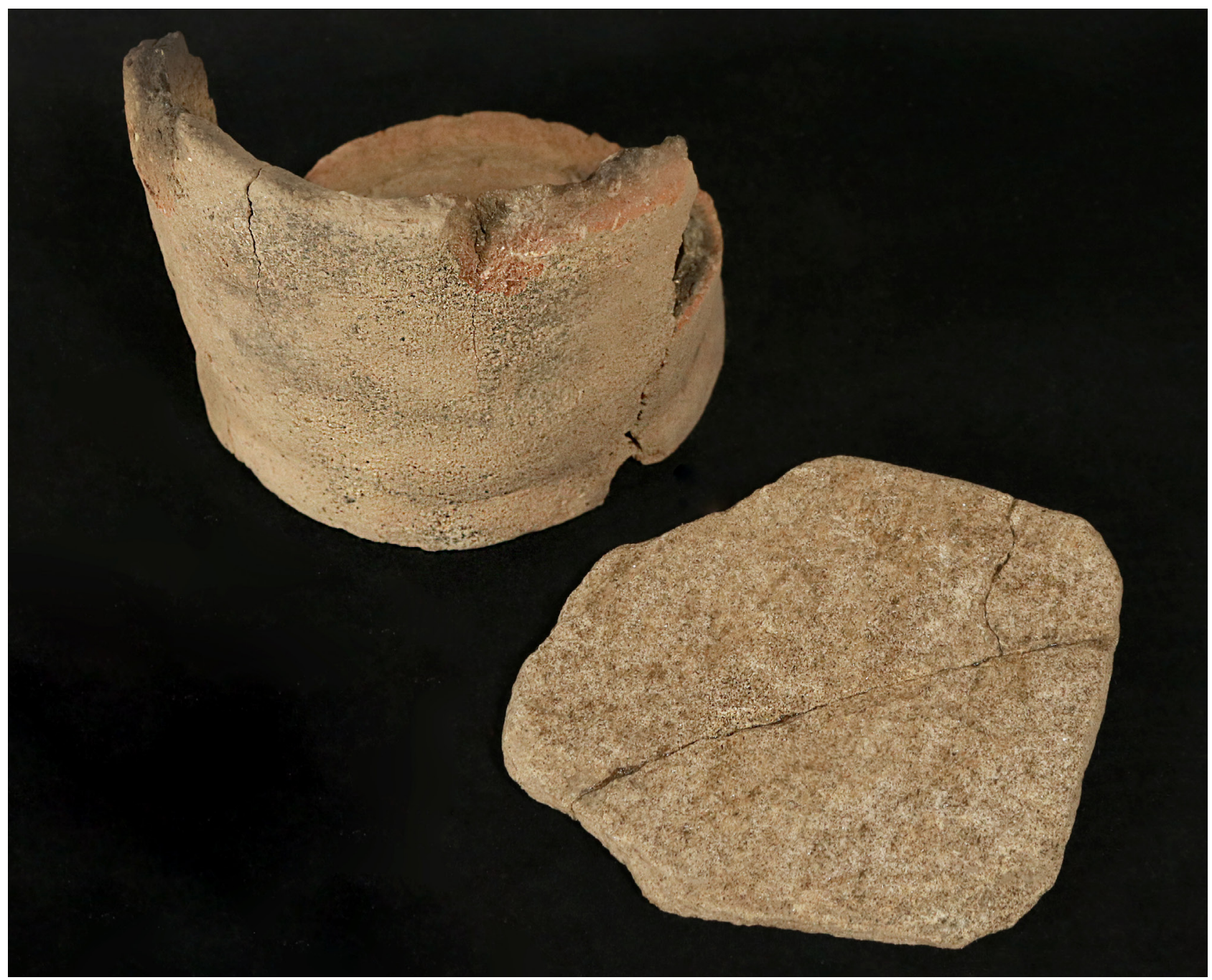

Illus 8 Vessel 1 with stone lid

Pit 061 immediately to the north-west of Pits 067 and 091 contained a stone grinder which may have been used to grind food or pigments. The surface of the grinder was well-worn, indicating that it may have been a favoured tool (see 4.5).

There were no finds recovered from Pits 059 and 122. The function and dating of all these pits is discussed in 5.1, below.

\subsection{Structure 2}

Structure 2 was a roundhouse located approximately $30 \mathrm{~m}$ to the south-east of Structure 1 (Illus 2). It comprised two opposing curvilinear ring ditches, an inner post ring, a south-east-facing entrance porch, a C-shaped post feature and a spread of material in the centre (Illus 3, 9 and 10). Initially, this was thought to be two separate roundhouses (Headland Archaeology 2019a; Structures 2 and 4), however, re-examination of the features, combined with the finds analysis, has identified that this was likely one structure; alternative layouts are discussed in section 5.2 .

The curvilinear ring ditches (Ring Ditches 149 and 151) had uneven sloping sides and concave bases, the implication being that they may have been formed from wear of the internal floor area of the roundhouse rather than being a cut, structural element. Large, poorly sorted stones were recorded in both ring ditches, although these predominated in the southern ditch and may have been for water management or to provide a hard, level surface to minimise further wear. The two ring ditches together had an outer diameter of $8.13 \mathrm{~m}$. Fragments of pottery from several vessels were recovered from the fills of both ring ditches and are discussed further below (4.1). A sample of alder charcoal from Ditch 151 was radiocarbon-dated to 


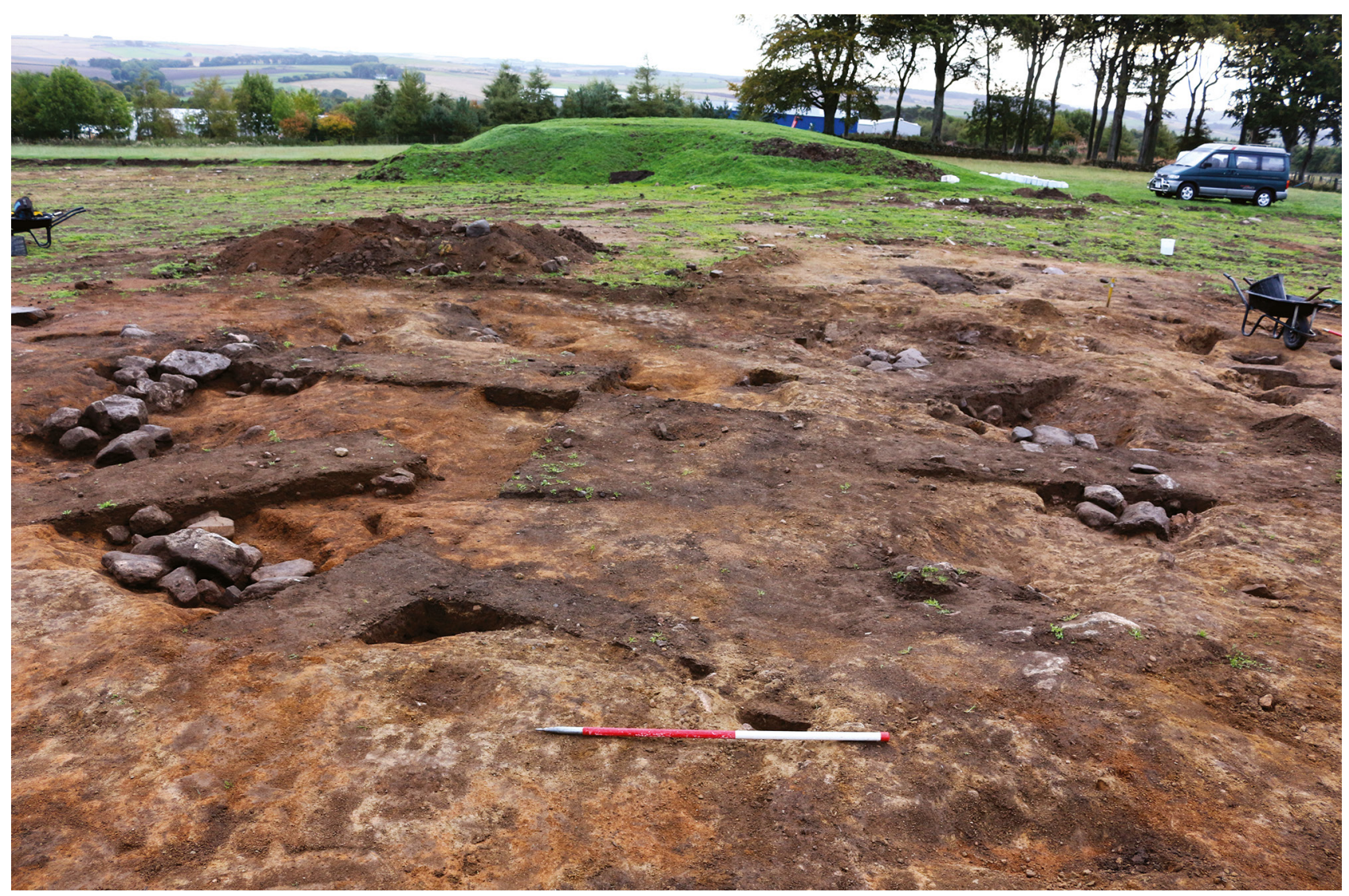

Illus 9 Mid-excavation of Structure 2, facing north-east

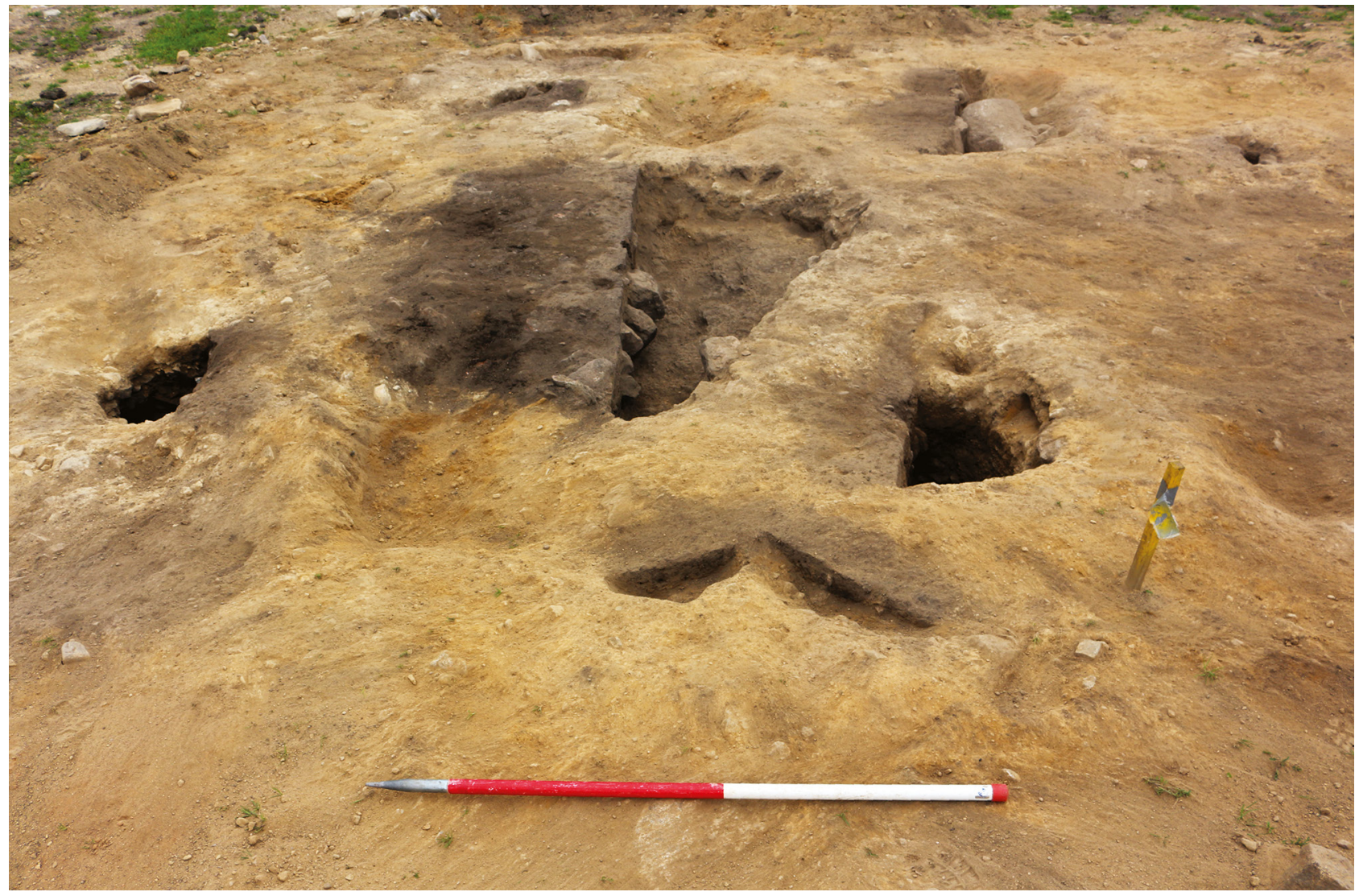

Illus 10 Entrance porch of Structure 2, facing east 
cal AD 415-540 (SUERC-93941; Table 1), placing it in the Early Historic period though it seems likely that this material is intrusive (see 5.2). A possible hide rubber was also recovered from the ditch (see 4.5).

A spread of clayey sand with charcoal inclusions (161) was present in the centre of the structure, enclosed by the curvilinear ring ditches. The natural geology and sediments below the deposit showed signs of discolouration, possibly due to being affected by heat. This deposit may have represented material associated with the collapse of the structure, such as wall panels and roofing material, or the remains of a small hearth. Pottery, including a fragment of 2nd-century AD samian ware, was recovered from the deposit (see 4.2). The deposit masked three post holes (157, 159 and 219), and a fourth (155) was located to the south of the deposit.

Remnants of an internal post ring comprising Post Holes 153, 165, 169 and 185 closely followed the external arc of Ditches 149 and 151. The three post holes in the west were relatively small in diameter (c $0.35 \mathrm{~m})$ and survived to a maximum depth of $c 0.14 \mathrm{~m}$. The shallow depth of the surviving post holes and complete absence of post holes on the north side suggests that the inner post ring was heavily truncated.

The rectangular entrance porch at the south-east of the structure was characterised by four large post holes (108, 120, 114 and 116). Post Hole 108 had a large packing stone at the base, which appeared to have settled in this location once the post had been removed, and Post Hole 120 had two packing stones set into the sides. Holly charcoal from Post Hole 120 returned a Middle Bronze Age radiocarbon date of 1505-1410 cal вс (SUERC-93918; Table 1 ), though, again, this seems unlikely to date the structure as it was likely residual (see 5.2). Centrally within the porch area, there was a large pit with poorly defined edges and an uneven base $0.29 \mathrm{~m}$ deep and a fill which included occasional poorly sorted large stones. As with the curvilinear ditches within the structure, this likely represented an area of wear as a heavy traffic area. A fragment of 1st- or 2 nd-century AD glass was recovered from this feature (see 4.3).

Post Holes 219, 159, 157, 155, 148, 103, 145, 110 and 112 formed a C-shaped feature in the interior of the structure and respected the entrance. Post Hole 57 was overlain by the later collapse material in Spread 161 and Post Hole 155 respected the position of the southern Ring Ditch 151, which suggested that they were contemporary.

No ring groove with stakeholes was identified around the perimeter of the structure, which suggested that the external wall was comprised of turf. As this has not survived, it is not possible to know the diameter of the roundhouse. However, the external wall would have encompassed the northeastern entrance of the souterrain, which would imply that the internal diameter exceeded $12 \mathrm{~m}$.

\subsection{Souterrain}

The souterrain was located immediately to the south of Structure 2, with the north-eastern end hooked under the putative line of the external wall of the roundhouse. It was a deeply cut, flat-bottomed curvilinear feature cutting the geological gravels and, in some areas, the bedrock. It originally comprised a single large chamber, the western end having been divided by a substantial, sloping rubble cross-wall. Overall, the souterrain was approximately $18 \mathrm{~m}$ long and up to $3.4 \mathrm{~m}$ wide, becoming narrower at the east end (Illus 11). It included rounded terminals, near-vertical sides $1.6 \mathrm{~m}$ deep and a base formed of bedrock. A shallow gully $0.1 \mathrm{~m}$ wide by $0.12 \mathrm{~m}$ deep was cut into the floor at the base of the walls (Illus 12), which may have been to aid drainage or act as a beam slot for supporting a wall lining.

The souterrain was partially lined with large, subrectangular stones, with the best-preserved areas at the north-eastern end, where clear coursing of the stones was present on both sides. The walls of the central area were not as clearly defined, and the stones here possibly represented collapsed wall material. Little of the wall survived across the western half of the souterrain, with the only surviving segment found abutted by the cross-wall (175), which was located to the western end of the structure (Illus 13 and 14). The cross-wall was constructed of large, poorly sorted boulders, larger than those used for the wall lining. The top of the wall was $0.75 \mathrm{~m}$ wide, formed of two rows of stones, with the base closer to $1.5 \mathrm{~m}$ wide. The wall abutted the souterrain wall lining at both ends, indicating that it formed a secondary phase of construction or use. This wall cordoned off the west end of the souterrain from the main chamber, creating a small, $1.4 \mathrm{~m}$-wide space 


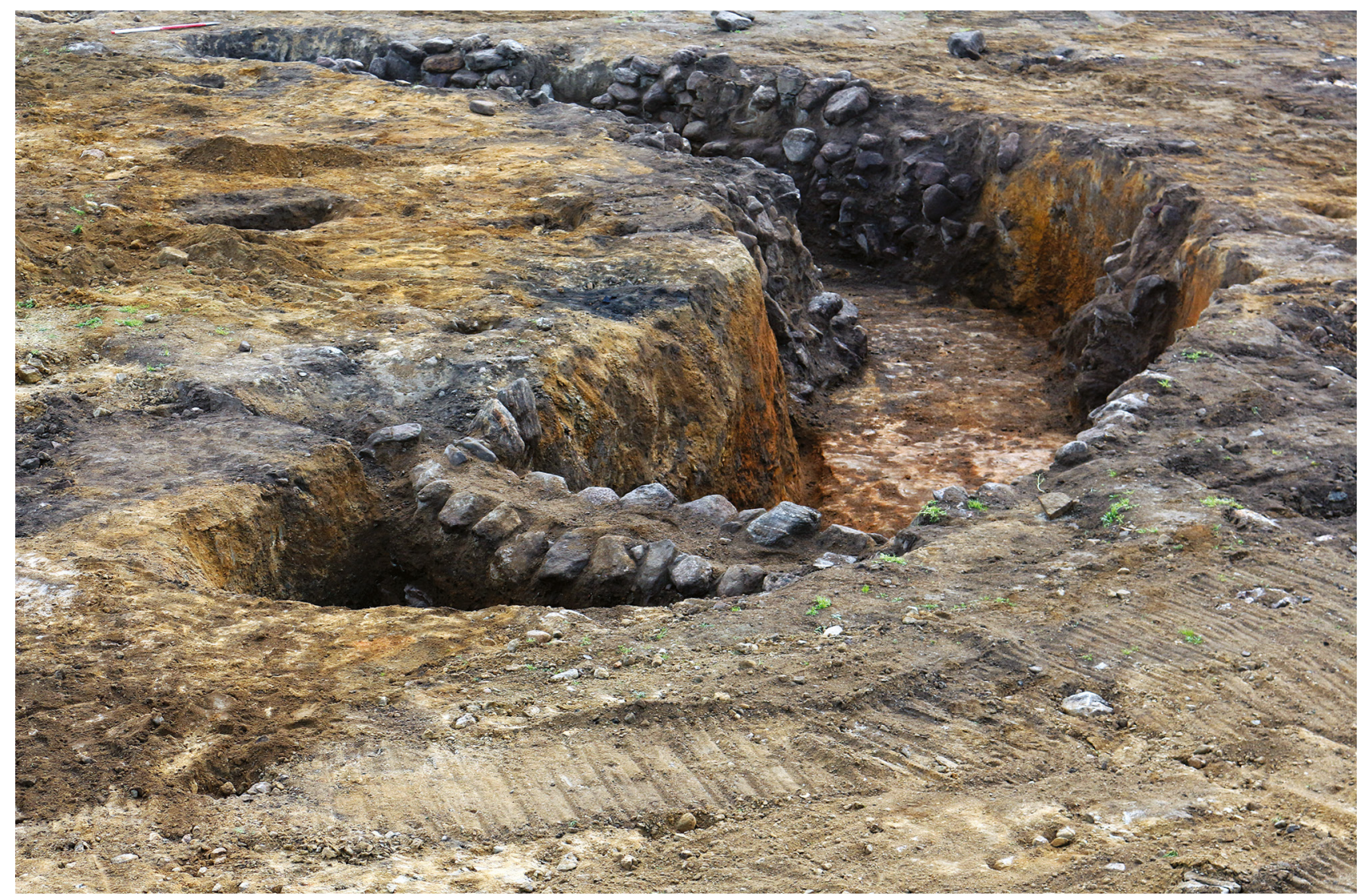

\section{Illus 11 Souterrain, looking east}

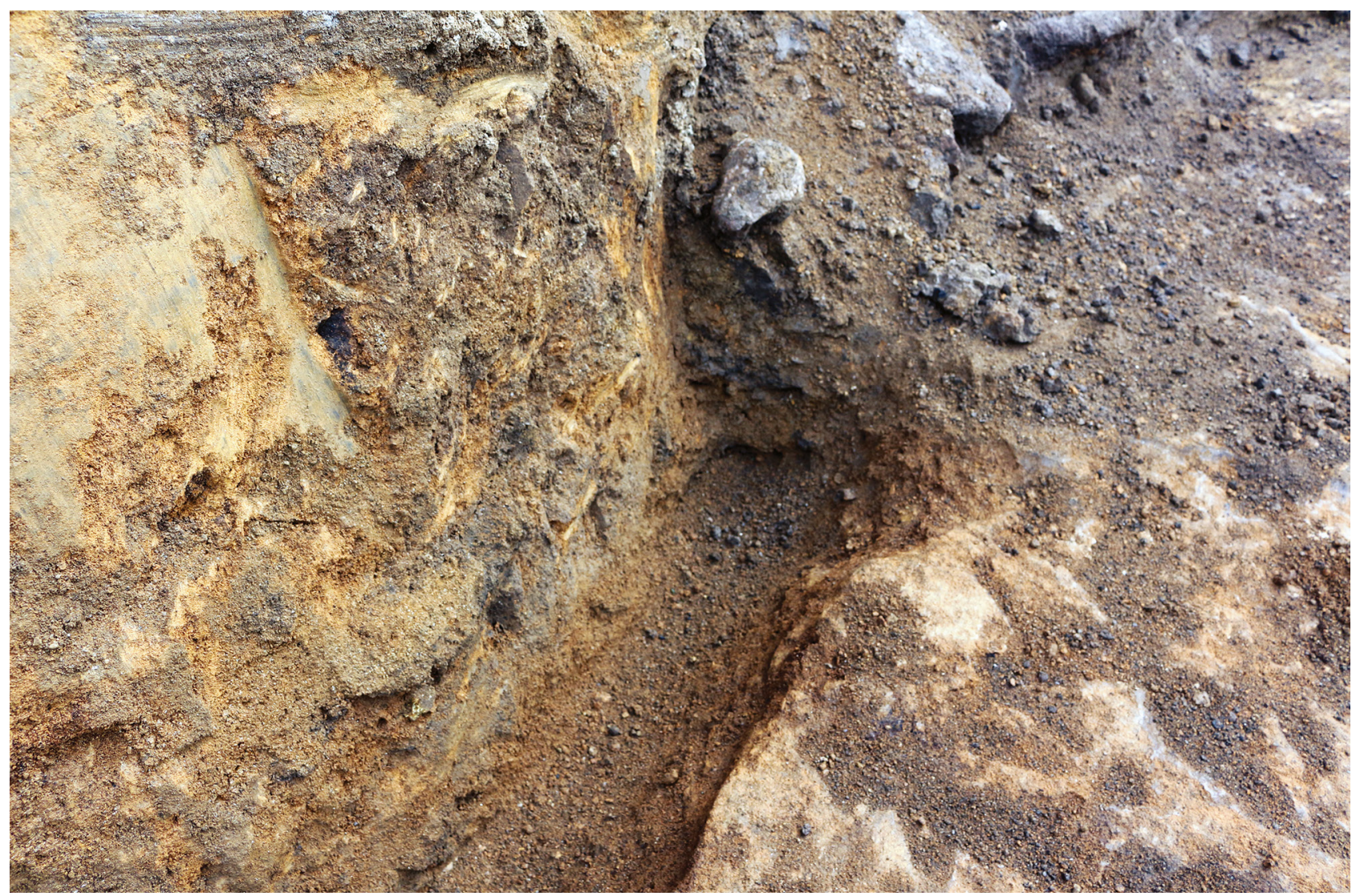

Illus 12 Souterrain floor showing the side gullies, facing north 


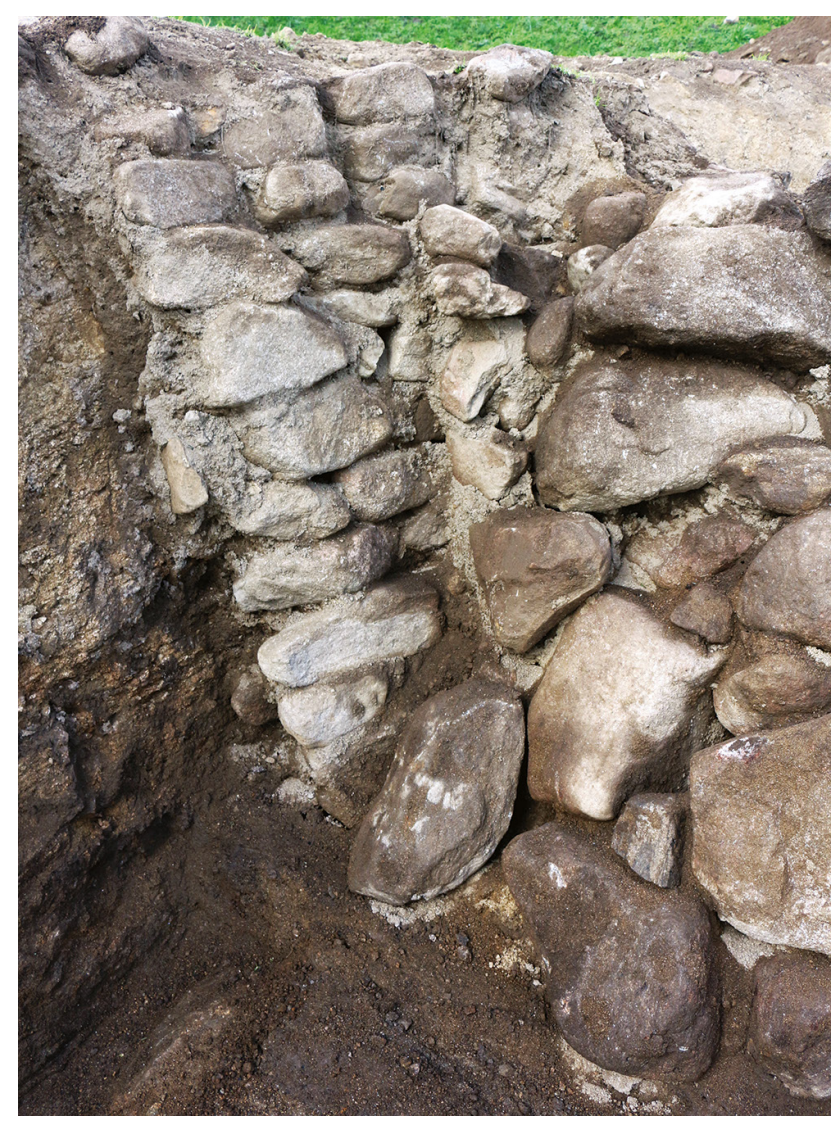

Illus 13 Detail of souterrain showing the crosswall abutting the original side wall, facing west behind it. This may have been purposely backfilled to support the cross-wall as it seemed to be undercut on this side, although the three distinct fills recorded in this area suggested a slower gradual infilling of the area.

Access to the souterrain was not immediately apparent. A series of three intercutting and gradually deeper pits $(213,215$ and 217$)$ to the north-west end of the souterrain provided a potential access point. These pits were possibly rudimentary steps leading into the structure, although this would still have left a drop of approximately $1.3 \mathrm{~m}$ to the base, suggesting that wooden steps or ladders may have been used. Pit 217, the lowermost of these, was located at the edge of the souterrain and aligned roughly with the cross-wall, which suggests they may have been contemporary. Two abraded saddle quern fragments and a rubber (see 4.5) and small quantities of undiagnostic pottery were recovered from the fill of Pit 217. This material may have been deliberately placed as a solid base for this step.

The primary deposits within the souterrain were present as a thin layer at the very base of the structure and contained small quantities of pottery,

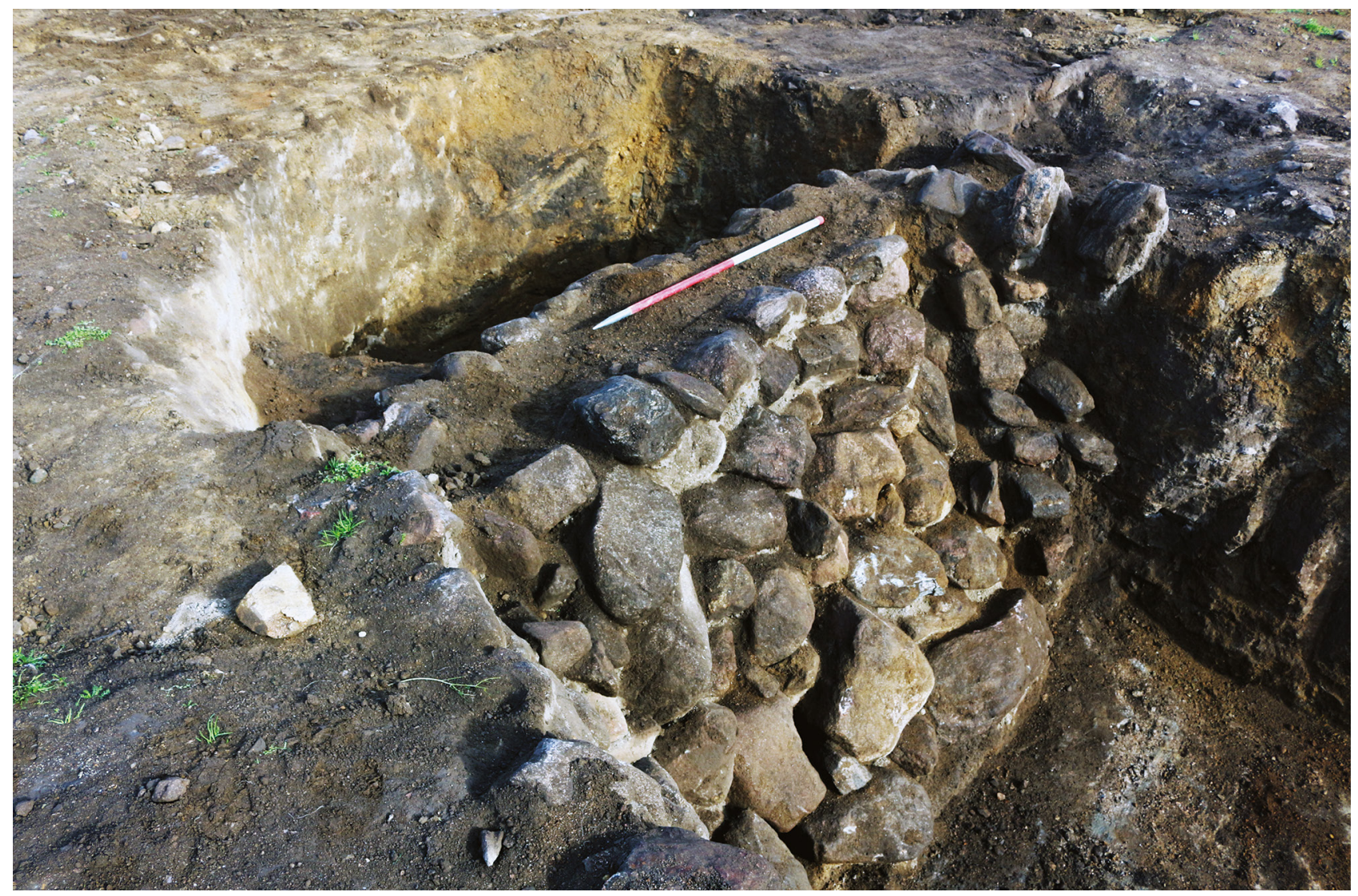

Illus 14 East-facing elevation of cross-wall of souterrain, facing north-west 
flecks of charcoal and small stones within a clayey sand. A stone sharpener or work surface was also recovered from this layer (see 4.5). These deposits may have been a debris layer accumulated during use or the initial stage of the abandonment of the structure. A sample of hazel charcoal from this primary deposit returned a Middle Iron Age radiocarbon date of cal AD 25-210 (SUERC-93914;

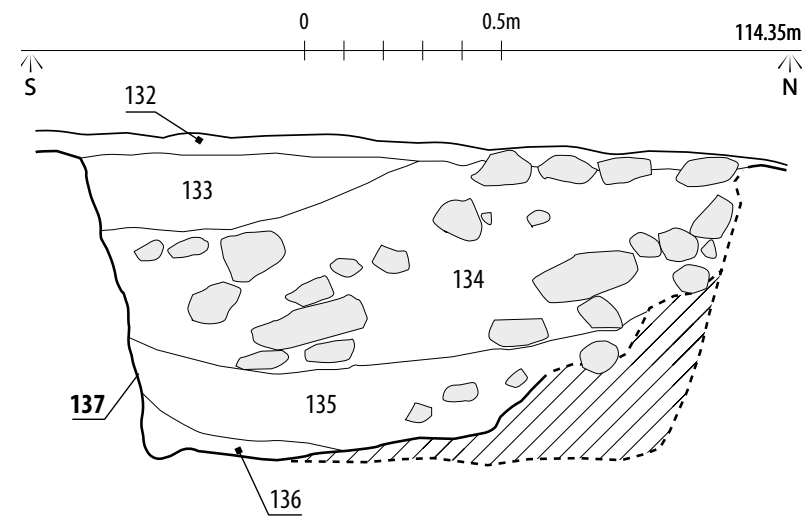

$/ /$, souterrain stone wall

Illus 15 West-facing section through the centre of the souterrain
Table 1). Subsequent fills within the souterrain were likely formed by wind and water carrying gravels and sands, mixed with periods of collapse from the roof and internal features such as wall linings or partitions (Illus 15 and 16). No empirical evidence for roof supports, such as post holes, was identified within the souterrain. This implies that the roof would have been supported by the surround walls, either laid horizontally over the top of the structure or forming a gable. This timber frame may have been removed prior to abandonment, as no evidence for larger timbers was identified. A fragment of a cannel coal bangle (see 4.4) was recovered from the topsoil overlying the souterrain and may have been waste from the occupation of the roundhouse and spread over the area post-abandonment.

\subsection{Feature Group 1}

Two features (005 and 017) were located in the south-west of Area B. During the excavation, it was assumed that these were cremation pits, based on the presence of burnt human bone within 017

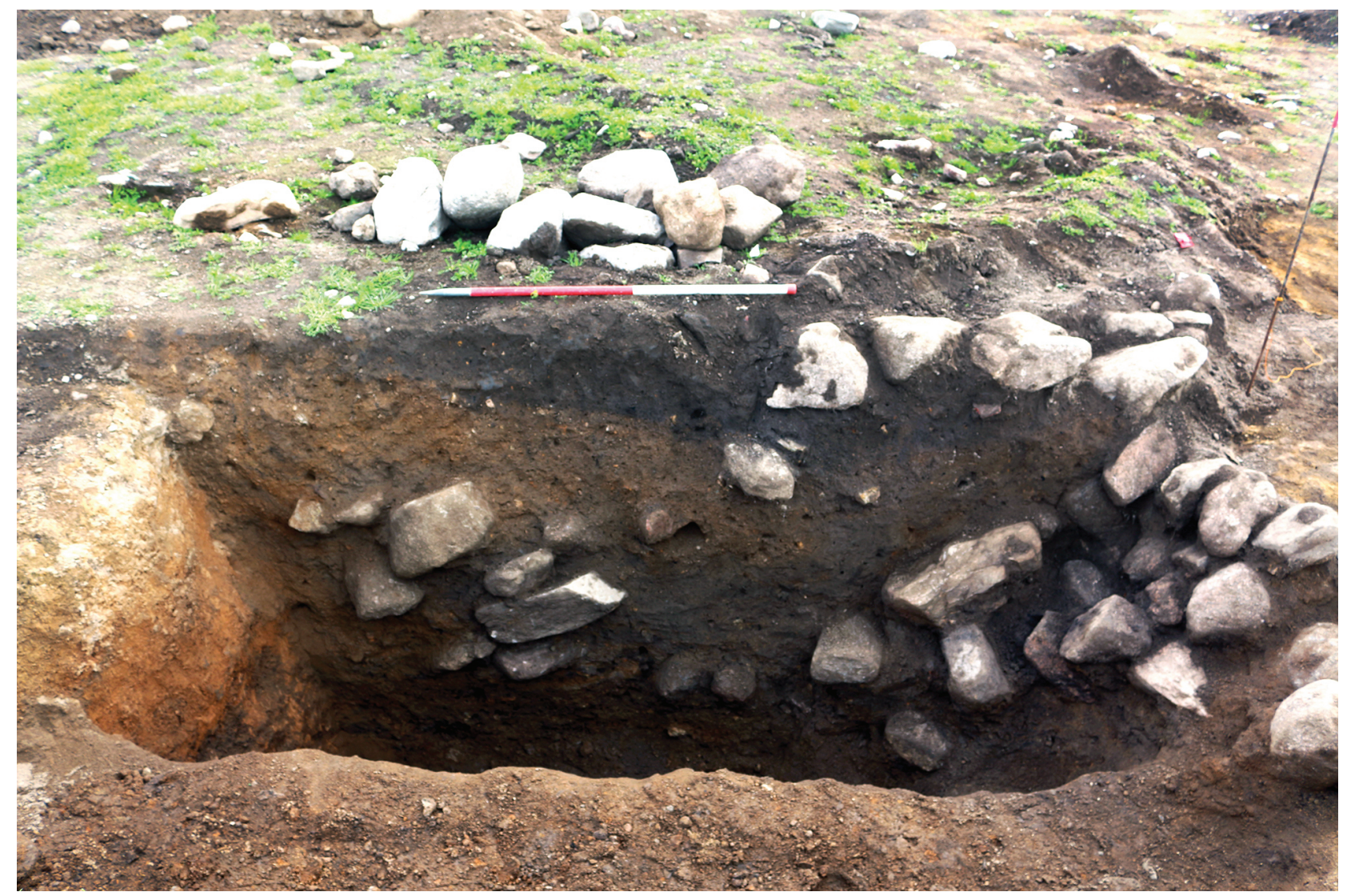

Illus 16 View of the deposits recorded within the souterrain during the preliminary stage of excavation, facing east 
(Headland Archaeology 2019a). Subsequently, these features have been reinterpreted as possible tree root hollows, based on their irregular shape in plan and uneven sides, with the cremated remains being possibly incidental, introduced either as rakings from funeral pyres, or as material from disturbed cremation burials nearby. Both features contained a similar sandy fill with inclusions of large stones and fragments of pottery from several vessels (see 4.1). Feature 005 contained heat-affected stones, while 017 contained cremated bone from two individuals and associated charcoal.

Feature 017 (Illus 17) contained a primary fill that contained cremated bone, overlain by a raft of stones with an average size of $0.3 \mathrm{~m}^{3}$. A further two deposits overlaid the stones and contained cremated bone. The skeletal material was analysed and represented at least two individuals: a probable adult and a child aged between two and six years old. The adult skeleton comprised fragments of skull, pelvis, vertebrae, leg, arm and a finger bone. The child skeleton comprised skull fragments, teeth, a rib shaft, a portion of the pelvis and an upper leg bone. An indeterminate long bone, probably from the adult skeleton, was subjected to radiocarbon dating and returned a Late Bronze Age date of 1055-900 cal вс (SUERC-93921; Table 1). As with the skeletal material in the urned cremation pits, the bone had been cremated at over $600^{\circ} \mathrm{C}$ and was fleshed at the time of cremation. The skeletal material was spread throughout three contexts, with no clear distinction made for individuals within fills.

Feature 005 contained a single deposit with inclusions of burnt stone, pottery fragments and ashes, although no in situ burning was noted. Although no cremated bone was found within this feature, the presence of the burnt stone and ashes may be related to funerary pyres.

\subsection{Feature Group 2}

A curvilinear ditch (030), two post holes (043 and $045)$ and eight pits $(021,022,025,027,028,034$, 036 and 039) were located at the eastern side of Area B. The curvilinear ditch was approximately $4 \mathrm{~m}$ in length and was uneven in plan. As with the curvilinear ditches associated with Structures 1 and 2 , the base had frequent, poorly sorted large stones

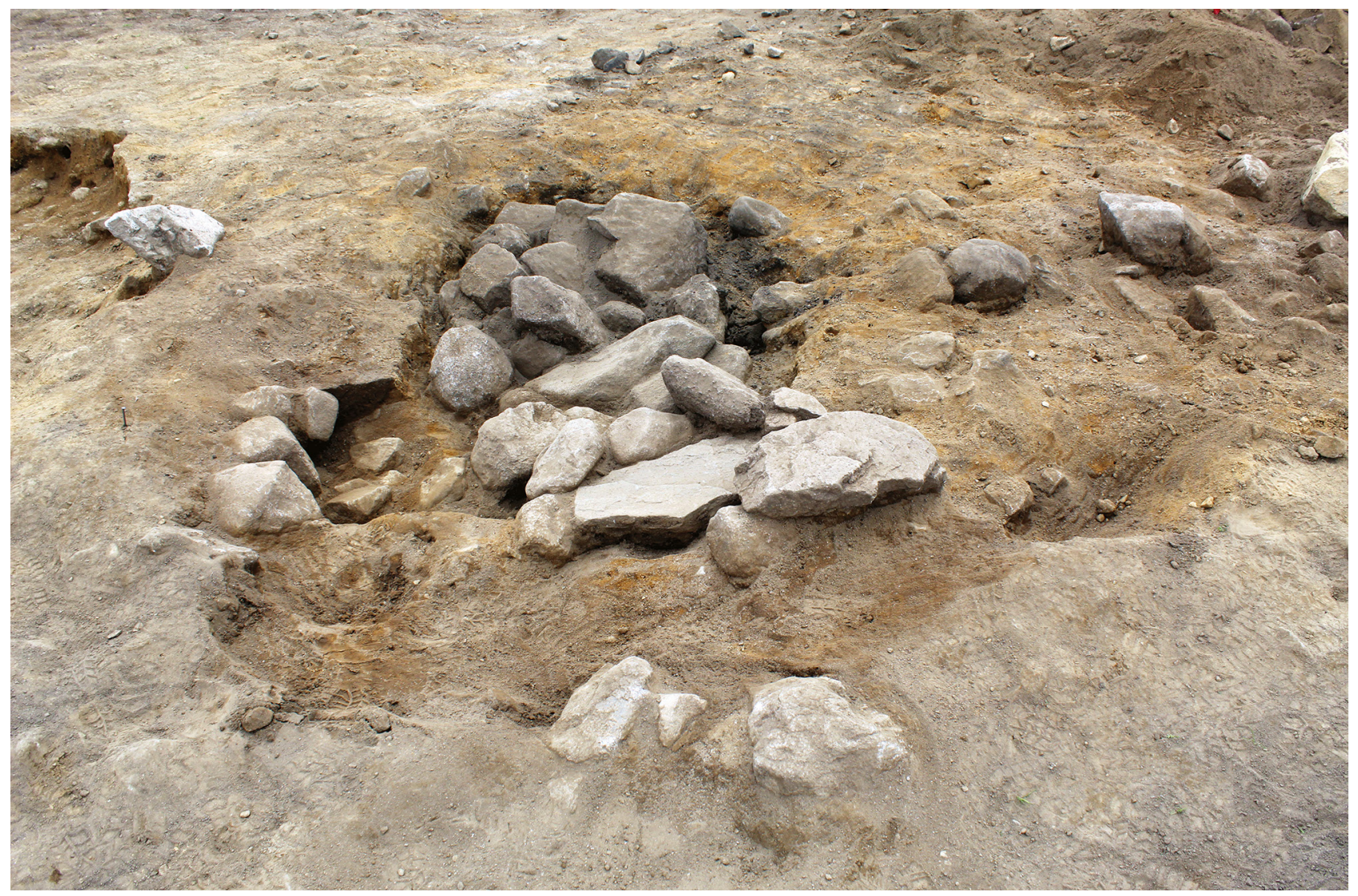

Illus 17 View of Treebole 017, facing west 
overlain with a dark brown sand. The similarities between the ditch and those of the roundhouses in Area A imply that this may also have been a roundhouse ring ditch, though more poorly preserved and smaller in size. Two shallow post holes were located immediately to the east which may have been associated structural elements.
There were eight sub-oval pits close to the ditch but they did not provide any insight into their function, nor could they be established as being part of a structure. Several fragments of pottery from the ditch and two of the pits could only be broadly dated as 'late prehistoric', but did not shed any light on the function of the features. 